\title{
PENGARUH PEMBERIAN JUS BIJI PEPAYA (CARICA PAPAYA LINN.) TERHADAP KADAR TRIGLISERIDA TIKUS SPRAGUE DAWLY DISLIPIDEMIA
}

\author{
Nuri Lydia Rahma, Ahmad Syauqy \\ Program Studi Ilmu Gizi Fakultas Kedokteran Universitas Diponegoro \\ Jl.Dr.Sutomo No.14, Semarang, Telp (024) 8453708, Email : gizifk@undip.ac.id
}

\begin{abstract}
Background: Cardiovascular disease is the leading causes of death in the world. One of the cardiovascular risk factor is dislipidemia, signed by highness triglyceride level in the blood. An appropriate management of triglyceride level can reduce risks of cardiovascular disease. Papaya seeds contain phytochemical elements such as flavonoid, saponin, and tannin which can lower the triglyceride level. This study aims to get the information on the effect of papaya seeds juice on triglyceride level in dislipidemic Sprague Dawley rats.

Methods: This study is a true experimental with pre-post test randomized control group design towards 24 Sprague Dawley dislipidemic rats which were randomized into 4 groups. There were negative control group that was only given standard diet, positive control group that were given standard and high fat diet, and two treatment groups that were given high fat diet also papaya seeds juice at dosages $400 \mathrm{mg}$ and $800 \mathrm{mg}$ for 30 days. Data were analysed by Paired t-test and Annova.

Result: Alteration of triglyceride level in negative control, positive control, and treatment groups that were given papaya seeds juice at dosages $400 \mathrm{mg}$ and $800 \mathrm{mg}$ respectively $0,2(p=0,985) ;-17,7(p=0,539) ;-13,3(p=0,214)$ dan 5,0 ( $p=0,506)$. Based on ANOVA test there was no difference between all groups $(p=0,685)$.

Conclusion: The administration of papaya seeds juice at dosages $400 \mathrm{mg} / \mathrm{rat} /$ day and $800 \mathrm{mg} / \mathrm{rat} /$ day for 30 days didn't decrease triglyceride level in dislipidemic Sprague Dawley rats.

Keyword : papaya seeds juice, flavonoid, saponin, tannin, triglyceride
\end{abstract}

\begin{abstract}
ABSTRAK
Latar Belakang : Penyakit kardiovaskuler merupakan penyebab utama kematian di dunia. Salah satu faktor risiko terjadinya penyakit ini ialah dislipidemia yang ditandai oleh tinggi nya kadar trigliserida dalam darah. Pengendalian kadar trigliserida yang tepat dapat mengurangi risiko penyakit kardiovaskuler. Biji pepaya mengandung zat fitokimia seperti flavonoid, saponin, dan tanin yang dapat menurunkan kadar trigliserida dalam darah. Penelitian ini bertujuan untuk mengetahui pengaruh jus biji pepaya terhadap kadar trigliserida pada tikus Sprague Dawly dislipidemia.

Metode: Penelitian ini merupakan penelitian true experimental dengan pre-post test randomized control group design yang menggunakan 24 ekor tikus Sprague Dawly dislipidemia. Pengelompokan dibagi secara acak menjadi 4 kelompok yaitu kelompok kontrol negatif yang hanya diberikan pakan standar, kontrol positif yang diberikan pakan standar dan tinggi lemak, dan dua kelompok perlakuan yang diberikan pakan standar, tinggi lemak dan jus biji pepaya dengan dosis $400 \mathrm{mg}$ dan $800 \mathrm{mg}$ selama 30 hari. Data dianalisis dengan uji Paired t-test dan Anova.

Hasil: Perubahan kadar trigliserida kelompok kontrol negatif, kontrol positif dan perlakuan $400 \mathrm{mg}$ dan $800 \mathrm{mg}$ secara berurutan adalah 0,2 ( $p=0,985) ;-17,7(p=0,539) ;-13,3(p=0,214)$ dan 5,0 $(p=0,506)$. Berdasarkan uji Anova tidak terdapat perbedaan perubahan kadar trigliserida antar kelompok $(p=0,685)$.

Simpulan: Pemberian jus biji pepaya dengan dosis $400 \mathrm{mg}$ dan $800 \mathrm{mg}$ per hari selama 30 hari tidak dapat menurunkan kadar trigliserida pada tikus Sprague Dawly dislipidemia.
\end{abstract}

Kata kunci : Jus biji pepaya, flavonoid, saponin, tanin, trigliserida

\section{PENDAHULUAN}

Penyakit kardiovaskuler merupakan penyebab utama kematian di dunia. ${ }^{1}$ Berdasarkan data WHO tahun 2008, 17.3 juta orang meninggal akibat penyakit ini dan diperkirakan akan meningkat menjadi 23.6 juta di tahun 2030. Satu per tiga kematian (sekitar 800.000) yang terjadi di Amerika tiap tahunnya disebabkan oleh penyakit kardiovaskuler. ${ }^{2,3}$ Tidak hanya di negara maju seperti Amerika, penyakit ini juga banyak terjadi di negara berkembang. ${ }^{4}$ Data WHO menyebutkan sekitar $80 \%$ kematian akibat penyakit ini terjadi di negara berkembang. Salah satunya negara Indonesia, berdasarkan hasil riset kesehatan dasar (Riskesdas) jumlah kematian penduduk akibat penyakit kardiovaskuler yaitu $31,9 \%$ di tahun 2007.

Untuk mengatasi tingginya angka kejadian penyakit kardiovaskuler, langkah efektif yaitu dengan mengurangi faktor risikonya. ${ }^{5}$ Dislipidemia merupakan salah satu faktor risiko terjadinya penyakit kardiovaskuler dimana kadar trigliserida, 
kolesterol total dan kolesterol LDL meningkat serta kolesterol HDL menurun. Suatu penelitian menyebutkan bahwapengobatan dislipidemia dapat mengurangi risiko penyakit kardiovaskuler sebesar $30 \%$ selama 5tahun. ${ }^{6}$

Terapi yang digunakan untuk mengembalikan profil lipid darah ke batas normal antara lain dengan terapi diet, aktivitas fisik, obatobatan dan suplementasi. ${ }^{4,7}$ Penggunaan zat fitokimia sebagai suplemen memiliki efek proteksi terhadap dislipidemia dan merupakan salah satu alternatif pengurangan angka kejadian penyakit kardiovaskuler. ${ }^{8}$ Penelitian terdahulu menyebutkan bahwa kandungan zat fitokimia dalam bawang putih (allicin) dan fenugreek (isoprenoids) dapat menurunkan serum trigliserida dan kolesterol LDL tanpa mempengaruhi kolesterol HDL, selain itu kandungan flavonoid pada teh hijau dan teh hitam (catechins dan galate esters) juga dapat menurunkan kolesterol darah. ${ }^{8}$ Suplementasi flavonoid jenis antosianin dengan dosis $80 \mathrm{mg}$ terbukti dapat menurunkan serum trigliserida , kolesterol LDL, kolesterol total serta meningkatkan kolesterol HDL pada pasien dislipidemia. ${ }^{9}$ Flavonoid jenis quercetin yang terkandung dalam buah pepaya diketahui dapat meningkatkan aktivitas lipoprotein lipase sehingga mempengaruhi kadar trigliserida serum tikus hiperkolesterolemia. ${ }^{10,1}$ Selain flavonoid, saponin dan tanin juga berperan dalam penurunan kadar trigliserida serum. Saponin dapatmenurunkan sintesis trigliserida dan absorbsi lemak serta meningkatkan oksidasi asam lemak. ${ }^{12,13}$ Tanin berperan dalam peningkatan aktivitas lipoprotein lipase sehingga mengakibatkan penurunan serum trigliserida. $^{14}$

Biji pepaya merupakan bahan alami yang mengandung zat fitokimia berupa flavonoid, saponin, tanin, dan antosianin yang bersifat sebagai hipolipidemia. $^{15,16}$ Beberapa penelitian berhasil membuktikan bahwa biji pepaya efektif menurunkan profil lipid darah. Salah satu penelitian yang dilakukan di Yogyakarta menyebutkan pemberian jus biji pepaya pada tikus Sprague Dawlyjantan dapat menurunkan kadar LDLplasma secara signifikan dengan dosis efektif $400 \mathrm{mg} / \mathrm{kgBB} / \mathrm{hari}$ selama 14 hari. ${ }^{15}$ Penelitian lain di Afrika menunjukkan bahwa ekstrak biji pepaya cair yang diberikan selama 30 harisecara oral sebanyak 100-400 $\mathrm{mg} / \mathrm{kgBB} / \mathrm{hari}$ dapat menurunkan kadar trigliserida, kolesterol total, kolesterol LDL dankolesterol VLDL, sertameningkatkan kadar kolesterol HDL secara signifikan pada tikus Wistar jantan. ${ }^{16}$ Penggunaan zat fitokimia sebagai suplemen dapat menimbulkan efek toksik. Berdasarkan penelitian, dosis aman pemberian ekstrak biji pepaya agar tidak mengakibatkan kematian pada tikus yaitu kurang dari $2000 \mathrm{mg} / \mathrm{kgBB} / \mathrm{hari}^{16}$

Tanaman pepaya (Carica papaya L) di Indonesia sangat mudah dijumpai, namun pemanfaatannya belum maksimal.Di negara ini buah dan daun saja yang dimanfaatkan.Biji pepaya cenderung dibuang dan hanya digunakan sebagai pelestarian tanaman.Penelitian mengenai manfaat biji pepaya sebagai hipolipidemia jarang dilakukan. Hanya satu penelitian yang meneliti efek biji pepaya terhadap kadar trigliserida yaitu penelitian yang dilakukan oleh Adeneye dan Olagunju yang membuktikan dosis 400 $\mathrm{mg} / \mathrm{kgBB} / \mathrm{hari}$ ekstrak biji pepaya cair dapat menurunkan serum trigliserida tikus Wistar jantan selama 30 hari. ${ }^{16}$ Diperlukan penelitian lanjut untuk membuktikan khasiat biji pepaya dalam bentuk olahan yaitu jus biji pepaya sebagai penurun kadar trigliserida pada tikus dislipidemia. Hal ini yang menjadi faktor pendorong dilakukannya penelitian mengenai efek pemberian jus biji pepaya terhadap kadar trigliserida tikus Sprague Dawlyjantan dislipidemia dengan dosis $400 \mathrm{mg} / \mathrm{ekor} / \mathrm{hari}$ dan $800 \mathrm{mg} / \mathrm{ekor} / \mathrm{hari}$ selama 30 hari.

\section{METODE PENELITIAN}

Penelitian true experimental dengan prepost test randomized control group design ini dilakukan di Laboratorium Fisiologi Hewan Jurusan Biologi Fakultas Matematika dan Ilmu Pengetahuan Alam Universitas Negeri Semarang (UNNES) dengan perlakuan pemberian jus biji pepaya (Carica papaya $L$ ) pada sampel tikus. ${ }^{17}$ Hasil yang dianalisis dalam penelitian ini ialah kadar trigliserida.

Sampel tikus yang digunakan yaitu tikus Sprague Dawleyjantan berusia 8 minggu dengan berat badan 150-180 gram yang diperoleh dari Laboratorium Farmasi Universitas Gajah Mada, Yogyakarta.Penentuan jumlahsampel minimal berdasarkan rumus Federerialah 6 ekor tiap kelompok.Pada awal penelitian menggunakan 7 ekor tikus tiap kelompok untuk mengantisipasi apabila terdapat tikus yang mati saat perlakuan.Selama penelitian, terdapat 4 ekor tikus yang drop out (1 ekor tikus masing-masing kelompok)sehingga jumlah sampel yang digunakan selama penelitian sebanyak 6 ekor tiap kelompok sesuai dengan jumlah sampel minimal.Penelitian ini menggunakan 4 kelompok perlakuan sehingga jumlah sampel yang digunakan sebanyak 24 ekor. 
Kelompok dalam penelitian ini yaitu kelompok kontrol negatif (K-), kontrol positif $(\mathrm{K}+)$, perlakuan jus biji pepaya $400 \mathrm{mg} / \mathrm{ekor} / \mathrm{hari}$ (P1) dan perlakuan jus biji pepaya 800 $\mathrm{mg} /$ ekor/hari (P2). Kelompok kontrol negatif hanya diberikan pakan standar. Kelompok kontrol positif diberikan pakan standar dan pakan tinggi kolesterol, sedangkan kelompok perlakuan jus biji pepaya diberikan sama seperti kelompok kontrol positif ditambah dengan jus biji pepaya dosis 400 mg/ekor dan $800 \mathrm{mg} / \mathrm{ekor}$. Seluruh subjek diberikan pakan standar BR-2 sebanyak 20 gram per hari serta minum air ad libitum.Selama penelitian dilakukan penimbangan berat badandan sisa pakan serta pembersihan kandang.

Sebelum intervensi, dilakukan perlakuan untuk membuat kondisi dislipidemia pada hewan coba kelompok kontrol positif dan kelompok perlakuan jus biji pepaya dengan pemberian pakan tinggi kolesteroldari kuning telur puyuh selama 30 hari.Pemilihan kuning telur puyuh sebagai pakan tinggi kolesterol dikarenakan kadar kolesterol yang terdapat pada kuning telur puyuh lebih tinggi dibanding telur lainnya yaitu sebanyak 2.139,17 $\mathrm{mg} / 100$ gram bahan makanan, selain itu kandungan lemaknya sebanyak 27,73 gram/100 gram. ${ }^{18,19}$ Kuning telur puyuh diblender dahulu kemudian diberikan sebanyak $2 \mathrm{ml} / \mathrm{ekor} / \mathrm{hari}$ dengan cara sonde.
Pembuatan jus biji pepaya dosis 400 $\mathrm{mg} / \mathrm{ekor} /$ hari dilakukan dengan cara menghaluskan biji pepaya menggunakan blender, kemudian ditimbang sebanyak $400 \mathrm{mg}$. Setelah itu ditambahkan dengan air hingga mencapai volume $1 \mathrm{ml}$ lalu disaring.Untuk jus biji pepaya dosis 800 $\mathrm{mg} / \mathrm{ekor} / \mathrm{hari}$ didapat dari dua kali pemberian dosis $400 \mathrm{mg} / \mathrm{ekor} / \mathrm{hari}$.Pemberian jus biji pepaya dengan cara sonde.

Pengambilan darah dilakukan sebanyak dua kali yaitu ketika sebelum perlakuan jus biji pepaya untuk melihat kadar trigliserida tiap kelompok sebelum intervensi dan setelah 30 hari masa intervensi untuk melihat pengaruh pemberian jus biji pepaya terhadap kadar trigliserida pada hewan coba. Sampel darah diambil melalui pleksus retroorbitalis sebanyak $2 \mathrm{ml}$ dan dimasukkan ke dalam tabung bersih, kemudian darah di-sentrifuge untuk mendapatkan serumnya. ${ }^{20}$ Kadar trigliserida dalam serum diukur dengan metode fotometri.

Data yang diperoleh diolah dengan program komputer.Data diuji normalitasnya menggunakan uji Shapiro-Wilk.Perbedaan kadartrigliserida sebelum dan setelah pemberian jus biji pepaya menggunakan uji Paired t-test. Perbedaan perubahan kadar trigliseridaantar keempat kelompokperlakuan dianalisis menggunakanuji Anova. ${ }^{21}$

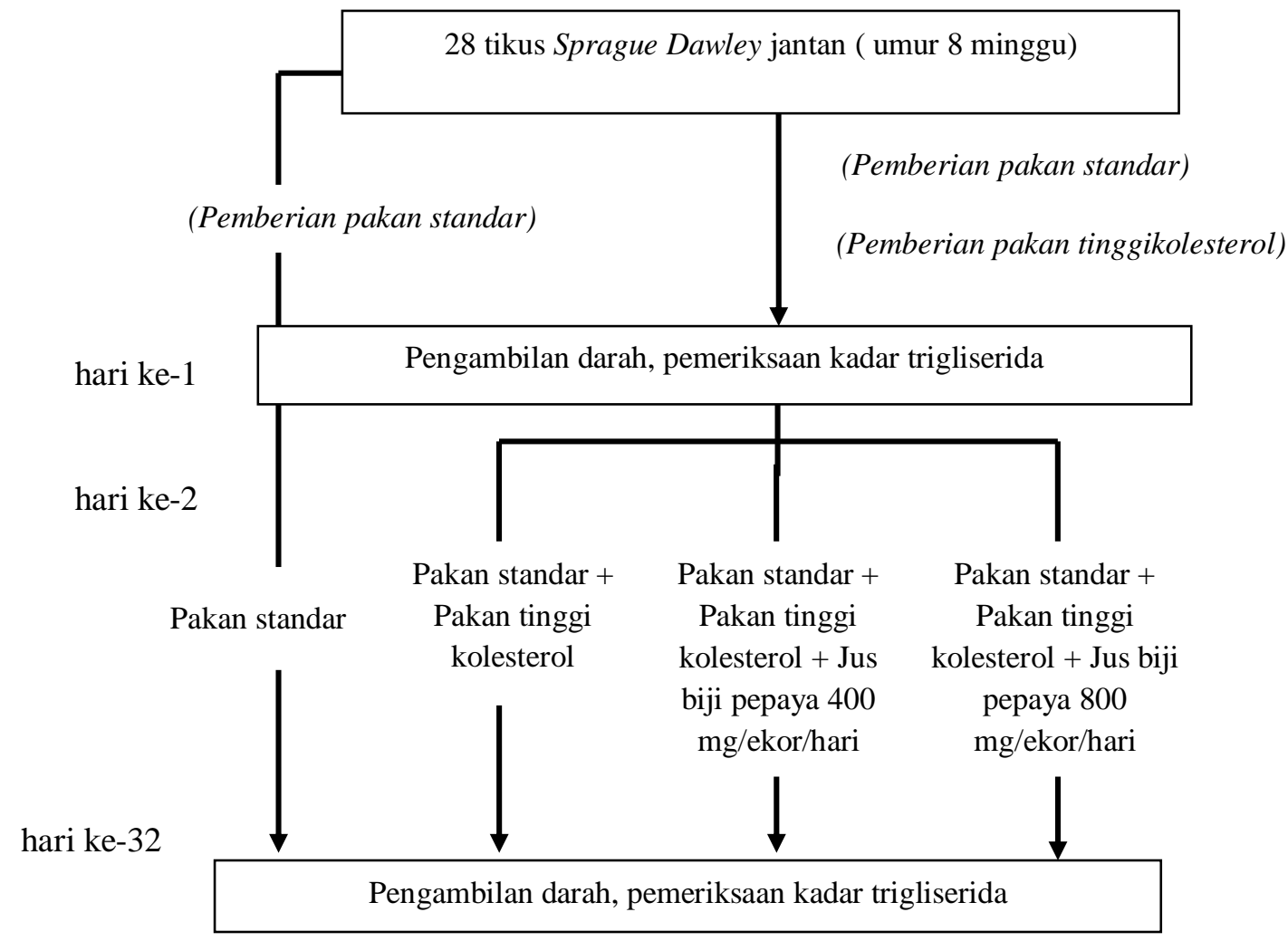

Gambar 1. Bagan AlurPenelitian 


\section{HASIL PENELITIAN}

Jumlah sampelpada penelitian ini sebanyak 28 ekor kemudian dibagi menjadi 4 kelompok yaitu kelompok kontrol negatif $(\mathrm{K}(-))$ yang selama penelitian hanya diberikan pakan standar, kelompok kontrol positif $(\mathrm{K}(+))$ yang selama penelitian diberikan pakan standar dan pakan tinggi kolesterol, kelompok perlakuan pertama (P1) yang diberikan pakan standar dan pakan tinggi kolesterolselama penelitian dan ditambah dengan pemberian jus biji pepaya dengan dosis $400 \mathrm{mg} / \mathrm{ekor} / \mathrm{hari}$ saat intervensi, serta kelompok perlakuan kedua (P2) yang diberikan pakan standar dan pakan tinggi kolesterolselama penelitian dan ditambah pemberian jus biji pepaya dengan dosis $800 \mathrm{mg} / \mathrm{ekor} / \mathrm{hari}$ saat intervensi.

\section{Kandungan zat jus biji pepaya}

Kandungan zat fitokimia dalam 100 gram biji pepayadan jus biji pepaya ditampilkan pada tabel 1.

Tabel 1. Kandungan zat fitokimiadalam 100 gram biji pepaya

\begin{tabular}{ccc}
\hline & $\begin{array}{c}\text { Biji pepaya } \\
\text { (mg/100g bahan) }\end{array}$ & $\begin{array}{c}\text { Jus biji pepaya } \\
\text { (mg/100 g bahan) }\end{array}$ \\
\hline Flavonoid & 947,7 & 646,1 \\
\hline Saponin & 88,39 & 69,3 \\
\hline Tanin & 189,35 & 140,9 \\
\hline Antosianin & 0 & 0 \\
\hline
\end{tabular}

Analisis fitokimia pada tabel 1diperoleh dari Laboratorium kimia Universitas Muhammadiyah Malang, Jawa Timur.Pengujian ini menggunakan sampel biji pepaya dan jus biji pepaya.Dari tabel diatas, terlihat bahwa kandungan zat fitokimia pada biji pepaya lebih tinggi dibandingkan dengan jus biji pepaya. Hal ini disebabkan oleh adanya proses penyaringan pada kelompok jus sehingga sebagian senyawanya terbuang dalam bentuk ampas.

\section{Karakteristik Sampel}

Dua puluh empatekor tikus Sprague Dawley jantandipelihara dalam kandang individu.Pemeliharaan dan pembersihan kandang dilakukansetiap hari oleh peneliti.

Penimbangan berat badan dilakukan 3-5 kali dalam seminggu sedangkan penimbangan sisa pakan dilakukan setiap hari selama penelitian.Hasil analisis rerata berat badan ditunjukkan pada tabel berikut.

Tabel 2. Hasil Analisis Rerata Berat Badan Sampel

\begin{tabular}{|c|c|c|c|c|c|c|}
\hline Kelompok & $\mathbf{n}$ & $\begin{array}{c}\text { Sebelum } \\
\text { Perlakuan } \\
\text { Rerata } \pm \text { SD } \\
\text { (g) }\end{array}$ & $\begin{array}{c}\text { Selama } \\
\text { Perlakuan } \\
\text { Rerata } \pm \text { SD } \\
\text { (g) }\end{array}$ & $\begin{array}{c}\Delta \\
\underset{(\mathrm{R})}{\operatorname{Rerata} \pm \mathrm{SD}}\end{array}$ & $\% \Delta$ & $p$ \\
\hline K- & 6 & $207,9 \pm 22,98$ & $262,8 \pm 30,73$ & $54,86 \pm 14,34^{\mathrm{a}}$ & 26,4 & $0,000^{\mathrm{b} *}$ \\
\hline $\mathrm{K}+$ & 6 & $203,7 \pm 11,83$ & $263,8 \pm 22,51$ & $60,12 \pm 27,22^{a}$ & 29,5 & $0,003^{b} *$ \\
\hline $\mathrm{P} 1$ & 6 & $219,8 \pm 23,53$ & $283,0 \pm 17,45$ & $63,18 \pm 8,49^{\mathrm{a}}$ & 28,7 & $0,000^{\mathrm{b} *}$ \\
\hline $\mathrm{P} 2$ & 6 & $211,9 \pm 9,66$ & $277,9 \pm 19,83$ & $66 \pm 13,52^{\mathrm{a}}$ & 31,1 & $0,000^{\mathrm{b} *}$ \\
\hline
\end{tabular}

${ }^{\mathrm{a} U j i}$ Anova

${ }^{\mathrm{b}}$ UjiPaired $t$-test $*$ berbeda bermakna

Berdasarkan hasil uji Paired t-test pada tabel 2 , terdapat perbedaan berat badan pada awal dan akhir penelitian.

Hasil analisis perubahan berat badan sampel yang diuji dengan uji Anova menunjukkan bahwa tidak terdapat perbedaan antar kelompok perlakuan
( $p=0,717)$. Secara deskriptif perubahan berat badan terendah yaitu pada kelompok K(-) sebesar 54.86 gram dan perubahan berat badan tertinggi yaitu pada kelompok P2 sebesar 66 gram.

Gambaran rerata asupan pakan tikus selama intervensi ditunjukkan pada gambar berikut. 


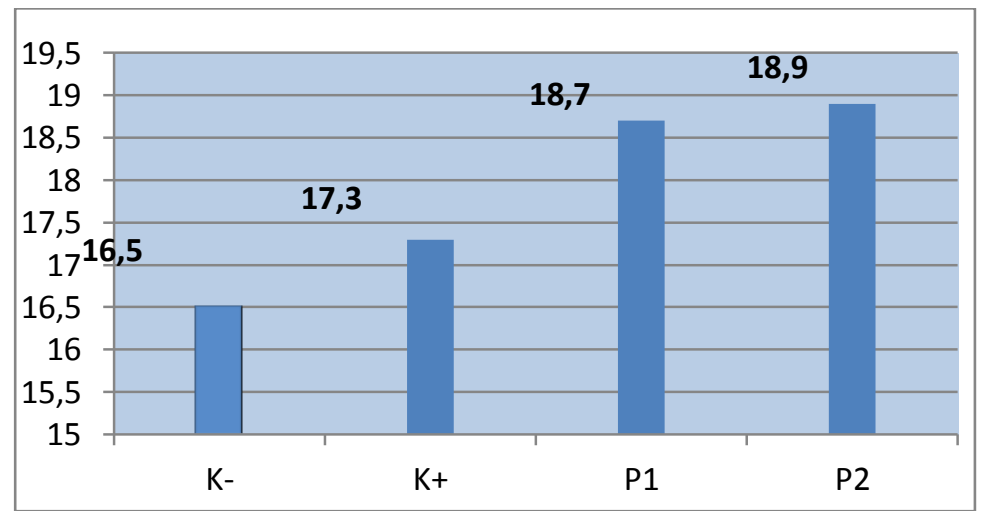

Gambar 2. Diagram asupan pakan selama intervensi

Dari Gambar 2 dapat dilihat bahwa asupan pakan tertinggi selama intervensi ialah kelompok P2 sedangkan asupan pakan terendah ialah kelompok K(-).

\begin{abstract}
Kadar Trigliserida Setelah Pemberian Pakan Tinggi Kolesterol

Tabel 3 menampilkan hasil analisis perbedaan kadar trigliserida kelompok yang tidak mendapat pakan tinggi kolesterol $\mathrm{K}(-)$ dengan kelompok yang mendapat pakan tinggi kolesterol $(\mathrm{K}(+), \mathrm{P} 1$, $\mathrm{P} 2)$ yang diuji menggunakan Independent $t$-test.
\end{abstract}

Tabel 3. Hasil Analisis Perbedaan Kadar Trigliserida Pre-Test

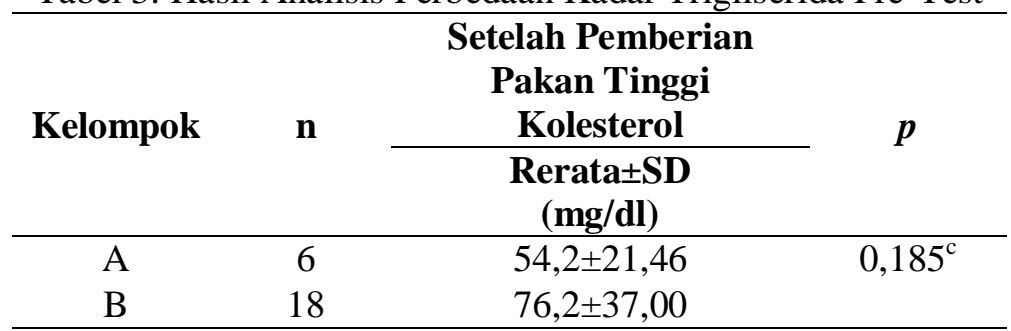

${ }^{\mathrm{c}} \mathrm{Uji}$ Independent $t$-test

Keterangan:

A: Kelompok yang tidak mendapat pakan tinggi kolesterol(K(-))

B: Kelompok yang mendapat pakan tinggi kolesterol( $K(+), P 1, P 2)$

Kadar TrigliseridaSebelum dan Setelah pepaya yang diuji menggunakan Paired $t$-testserta Pemberian Jus Biji Pepaya menampilkan hasil analisis perbedaan Tabel 4 menampilkan hasil analisis kadar perubahan( 4$)$ kadar trigliserida antar kelompok trigliserida sebelum dan setelah pemberian jus biji yang diuji menggunakan uji Anova.

Tabel 4. Hasil Analisis Kadar Trigliserida

\begin{tabular}{|c|c|c|c|c|c|c|}
\hline Kelompok & $\mathbf{n}$ & $\begin{array}{c}\text { Sebelum } \\
\text { Perlakuan } \\
\text { Rerata } \pm \text { SD } \\
(\mathrm{mg} / \mathrm{dl})\end{array}$ & $\begin{array}{c}\text { Setelah } \\
\text { Perlakuan } \\
\text { Rerata } \pm \text { SD } \\
(\mathbf{m g} / \mathbf{d l})\end{array}$ & $\underset{(\mathbf{m g} / \mathrm{dl})}{\operatorname{Rerata} \pm \mathrm{SD}}$ & $\% \Delta$ & $p$ \\
\hline K- & 6 & $54,2 \pm 21,46$ & $54,3 \pm 13,94$ & $0,2 \pm 20,35^{\mathrm{a}}$ & 0,3 & $0,985^{b}$ \\
\hline $\mathrm{K}+$ & 6 & $102,8 \pm 49,88$ & $85,2 \pm 52,06$ & $\begin{array}{c}- \\
17,7 \pm 65,63^{\mathrm{a}}\end{array}$ & $-17,2$ & $0,539^{b}$ \\
\hline $\mathrm{P} 1$ & 6 & $70,7 \pm 24,80$ & $57,3 \pm 11,88$ & $13,3 \pm 22,95^{\mathrm{a}}$ & $-18,8$ & $0,214^{\mathrm{b}}$ \\
\hline $\mathrm{P} 2$ & 6 & $55,0 \pm 11,15$ & $60,0 \pm 9,59$ & $5,0 \pm 17,08^{\mathrm{a}}$ & 9 & $0,506^{\mathrm{b}}$ \\
\hline
\end{tabular}


Tabel 4menunjukkan bahwa tidak terdapat perbedaan kadar trigliserida sebelum dan setelah pemberian jus biji pepaya. Kadar trigliserida pada kelompok P2 seharusnya mengalami penurunan namun pada penelitian ini mengalami peningkatan. Begitu juga kadar trigliserida pada kelompok $\mathrm{K}(+)$ yang seharusnya mengalami peningkatan namun pada penelitian ini mengalami penurunan.

Hasil analisis perubahan kadar trigliserida menunjukkan bahwa tidak terdapat perbedaan antar kelompok perlakuan $(p=0,685)$. Secara deskriptif penurunan kadar trigliserida tertinggi terdapat pada kelompok K(+)yaitu sebesar 17,7 $\mathrm{mg} / \mathrm{dl}$, sedangkan peningkatan kadar trigliserida tertinggi terdapat pada kelompok $\mathrm{P} 2$ yaitu sebesar $5 \mathrm{mg} / \mathrm{dl}$.

\section{PEMBAHASAN}

\section{Kandungan Zat Jus Biji Pepaya}

Kandungan zat fitokimia pada biji pepaya diuji di Laboratorium Kimia Universitas Muhammadiyah Malang, Jawa Timur menggunakan sampel biji pepaya dan jus biji pepaya.Dari hasil yang ditampilkan pada tabel 1 , terlihat bahwa kandungan fitokimia yang ada pada biji pepaya yaitu flavonoid, saponin dan tanin sedangkanflavonoid jenis antosianin tidak terkandung didalam biji pepaya.Hal ini berbeda dengan penelitian terdahulu yang menyebutkan bahwa antosianin terkandung dalam biji pepaya. ${ }^{16}$ Perbedaan ini kemungkinan disebabkan oleh perbedaan jenis varietas pepaya yang digunakan pada penelitian terdahulu.

Kandungan fitokimia yang terdapat pada 100 gram biji pepaya yaitu flavonoid sebanyak $947,7 \mathrm{mg}$; saponin $88,39 \mathrm{mg}$ dan tanin $189,35 \mathrm{mg}$. Untuk kandungan 100 gram jus biji pepaya yaitu flavonoid sebesar $646,1 \mathrm{mg} ; 69,3 \mathrm{mg}$ saponin dan $140,9 \mathrm{mg}$ tanin. Terlihat bahwa kandungan zat fitokimia pada biji pepaya lebih tinggi dibandingkan dengan jus biji pepaya. Hal ini disebabkan oleh adanya proses penyaringan pada kelompok jus sehingga sebagian senyawanya terbuang dalam bentuk ampas.

Penelitian terdahulu menyebutkan bahwa biji pepaya mengandung flavonoid, saponin, tanin dan alkaloid. ${ }^{16}$ Flavonoid dan tanin dapat meningkatkan aktivitas lipoprotein lipase sehingga dapat menurunkan kadar trigliserida dalam plasma. ${ }^{10,11,14}$ Saponin dapat menurunkan sintesis trigliserida dan absorbsi lemak serta meningkatkan oksidasi asam lemak. ${ }^{12,13}$ Alkaloid memiliki efek hipolipidemik namun dalam penggunaannya dapat menyebabkan efek toksik. ${ }^{8,16,26}$

\section{Pakan Tinggi Kolesterol}

Pada penelitian ini pengkondisian tikus menjadi dislipidemia menggunakan pakan tinggikolesterolyaitu kuning telur puyuh.Pemilihan kuning telur puyuh sebagai pakan tinggi kolesterol dikarenakan kadar kolesterol yang terdapat pada kuning telur puyuh lebih tinggi dibanding telur lainnya yaitu sebanyak 2.139,17 mg/100 gram bahan makanan, selain itu kuning telur puyuh memiliki kandungan lemak sebanyak 27,73 gram $/ 100$ gram. ${ }^{18,19}$ Pemberian telur puyuh selama 4 minggu dapat mengakibatkan kondisi dislipidemia dengan meningkatkan kadar kolesterol total, kolesterol LDL, kolesterol VLDL serta menurunkan kolesterol HDLpada tikus Wistar jantan. ${ }^{18}$ Untuk mengetahui apakah pemberian pakan tinggi kolesterol dapat mempengaruhi kadar trigliserida sampel yaitu dengan membandingkan kadar trigliserida kelompok yang tidak diberi pakan tinggi kolesterol $(\mathrm{K}(-))$ dengan kelompok yang diberi pakan tinggi kolesterol $(\mathrm{K}(+), \mathrm{P} 1, \mathrm{P} 2)$.

Tabel 3 menunjukkan bahwa tidak terdapat perbedaan kadar trigliserida antara kelompok yang tidak diberi pakan tinggi kolesterol dengan kelompok yang diberi pakan tinggi kolesterol $(p>0.05)$.

Kolesterol yang berasal dari makanan akan disimpan dalam tubuh sebagai kolesterol bukan sebagai trigliserida, sedangkan trigliserida dalam tubuh berasal dari lemak dan karbohidrat makanan. ${ }^{23,25}$ Penelitian yang dilakukan oleh Intan menyebutkan bahwapemberian pakan tinggi lemak yang dibuat dengan cara mencampurkan pakan standar dengan $10 \%$ lemak babi(kandungan lemak 1,3 gram/hari)selama 14 hari dapat meningkatkan kadar trigliserida sampel. ${ }^{29}$ Jumlah pemberian lemak pada penelitian ini sebesar 0,56 gram/hari selama 30 hari, jumlah ini dibawah jumlah yang diberikan pada penelitian sebelumnya. Hal ini menunjukkan bahwa diperlukan asupan lemak yang lebih tinggi untuk dapat meningkatkan kadar trigliserida sampel.

\section{Kadar TrigliseridaSebelum SetelahPemberian Jus Biji Pepaya}

dan

Hasil dari penelitian ini menunjukkan bahwa tidak terdapatperbedaankadar trigliserida sebelum dan setelah pemberian jus biji pepaya pada semua kelompok perlakuan.Secara deskriptif kelompok P1 mengalami penurunan sebesar 18,8\% sedangkan kelompok P2 yang seharusnya mengalami penurunan namun pada penelitian ini mengalami peningkatan sebesar 9\%.Hasil analisis 
perubahan kadar trigliserida menunjukkan tidak terdapat perbedaan antar kelompok $\mathrm{K}(-), \mathrm{K}(+), \mathrm{P} 1$ dan P2. Halini menunjukkan bahwa pemberian jus biji pepaya tidak dapat menurunkan kadar trigliserida tikus Sprague Dawleydislipidemia.

Pada kelompok $\mathrm{K}(+)$ diberikan pakan standar dan pakan tinggi kolesterol. Kadar trigliserida pada kelompok $\mathrm{K}(+)$ mengalami penurunan sebesar $17,2 \%$. Berdasarkan analisis kadar trigliserida setelah pemberian pakan tinggi kolesterol pada Tabel 3 menunjukkan bahwa pakan tinggi kolesterol tidak dapat meningkatkan kadar trigliserida sampel. Oleh karena itu kadar trigliserida pada kelompok $\mathrm{K}(+)$ dapat mengalami penurunan meskipun diberi pakan tinggi kolesterol selama intervensi. Perubahan berat badan dan asupan pakan selama intervensi padakelompok $\mathrm{K}(+)$ lebih rendah dibandingkan dengan kelompok perlakuan jus biji pepaya sehingga kadar trigliserida pada kelompok $\mathrm{K}(+)$ dapat mengalami penurunantanpa pemberian jus biji pepaya.Asupan pakan yang rendah menyebabkan peningkatan oksidasi asam lemak untuk bahan bakar metabolik sehingga sisa asam lemak untuk sintesis trigliserida menurun.Penurunan sintesis trigliserida menyebabkan kadar trigliserida dalam darah menurun. ${ }^{24,25}$

Pada kelompok P1 diberikan pakan standar dan pakan tinggi kolesterolselama penelitian ditambahkan pemberian jus biji pepaya 400 mg/ekor ketika masa intervensi 30 hari. Kadar trigliserida pada kelompok P1 mengalami penurunan sebesar $18,8 \%$. Penyebab penurunan ini diduga karena kandungan flavonoid, tanin dan saponin yang terdapat dalam jus biji pepaya.Flavonoid dan tanin meningkatkan aktivitas lipoprotein lipase sehingga kadar trigliserida dalam plasma menurun. ${ }^{10,11,14}$ Saponin menurunkan sintesis trigliserida dan absorbsi lemak serta meningkatkan oksidasi asam lemak. $^{12,13}$

Pada kelompok P2 diberikan pakan standar dan pakan tinggi kolesterolselama penelitian ditambahkan pemberian jus biji pepaya 800 mg/ekor ketika masa intervensi 30 hari.Kadar trigliserida pada kelompok P2 seharusnya mengalami penurunan namun pada penelitian ini mengalami peningkatan sebesar 9\%.Peningkatan kadar trigliserida pada kelompok P2 dimungkinkan akibat konsumsi jus biji pepaya pada dosis tinggi bukannya memberi efek penurunan kadar trigliserida yang lebih besarjustru menyebabkan efek hepatotoksik pada sampel.Penelitian yang dilakukan oleh Ibekwe menyebutkan bahwa pemberian alkaloid dengan dosis $100 \mathrm{mg} / \mathrm{kgBB}$ pada tikus dapat menurunkan kadar kolesterol total dan kolesterol LDL namun kadar trigliserida tidak mengalami penurunan melainkan mengalami peningkatan, selain itu terjadi gangguan fungsi hati akibat pemberian intervensi alkaloid. ${ }^{26}$ Interaksi antara toksikan dari tanaman dengan struktur reseptor tertentu yang ada di sel hati menyebabkan terjadinya kerusakan pada membran sel. ${ }^{27}$ Enzim lipoprotein lipase yang bekerja menghidrolisis trigliserida untuk melepaskan asam lemak terletak pada membran sel. Kerusakan membran sel menyebabkan inaktivasi enzim lipoprotein lipase sehingga kadar trigliserida dalam plasma tinggi karena trigliserida tidak dihidrolisis. ${ }^{27}$ Selain kerusakan pada membran sel, hepatotoksik dapat terjadi akibat disfungsi mitokondria dimana mitokondria merupakan tempat berlangsunya proses oksidasi asam lemak. Asam lemak hasil hidrolisis trigliserida oleh lipoprotein lipase yang ada di membran sel akan masuk kedalam mitokondria untuk proses oksidasi asam lemak atau diubah kembali menjadi trigliserida. Apabila proses oksidasi asam lemak menurun akibat disfungsi mitokondria maka asam lemak tidak dapat dijadikan bahan bakar metabolisme dan akan diubah menjadi trigliserida kembali. Hal ini mengakibatkan peningkatan kadar trigliserida plasma. $^{28}$

\section{KETERBATASAN PENELITIAN}

Keterbatasan penelitian ini ialah tidak dilakukan uji kandungan alkaloid pada jus biji pepaya serta tidak dilakukan uji toksistasjus biji pepaya berbagai dosis.

\section{SIMPULAN}

Pemberian jus biji pepaya dengan dosis $400 \mathrm{mg} / \mathrm{ekor} / \mathrm{hari}$ dan $800 \mathrm{mg} / \mathrm{ekor} / \mathrm{hari}$ selama 30 hari tidak dapat menurunkan kadar trigliserida tikus Sprague Dawleydislipidemia.

\section{SARAN}

Pada penelitian selanjutnya perlu dilakukan uji toksisitasjus biji pepaya berbagai dosis untuk menentukan dosis aman pemberian jus biji pepaya agar tidak menimbulkan efek hepatotoksik pada sampel.

\section{UCAPAN TERIMA KASIH}

Puji syukur kepada Allah SWT, terima kasih kepada Bapak Ahmad Syauqy S.Gz, MPH selaku pembimbingdan para reviewer yang telah membimbing penelitian ini hingga dapat terlaksana 
sampai akhir.Selain itu terima kasih kepada orang tua dan teman-teman atas dukungan yang telah diberikan selama penelitian ini berlangsung.

\section{DAFTAR PUSTAKA}

1. Libby P, Bonow RO, Mann DL, Zipes DP. Hearth disease "a text book of cardiovascular medicine" eight edition. USA: Saunders; 2008.

2. Roger VL, Go AS, Lloyd-Jones DM, Adams RJ, Berry JD, Brown TM, et al. Heart disease and stroke statistics 2011 update: a report from the American Heart Association. Circulation 2011;123:18-209.

3. Heidenreich PA, Trogdon JG, Khavjou OA, Butler J, Dracup K, Ezekowitz MD, et al. Forecasting the future of cardiovascular disease in the United States: a policy statement from the American Heart Association. Circulation 2011;123:933-44.

4. Afoakwah AN, Owusu WB. The relationship between dietary intake, body composition and blood pressure in male adult miners in ghana. Asian Journal of Clinical Nutrition 2011;3:1-13.

5. Cooper RS, Orduñez P, Ferrer MDI,Munoz JLB, Brito AE. Cardiovascular disease and associated risk factors in cuba: prospects for prevention and control. American Journal of Public Health 2006; Vol 96, no 1

6. Grundy SM, Cleeman JI, Merz CNB, Brewer HB, Hunninghake DB, Pasternak RC, et al.Implications of recent clinical trials for the national cholesterol education program adult treatment panel III guidelines. American Hearth Association 2004;110:227-239.

7. National Institutes of Health. Third report of the National Cholesterol Education Program (NCEP) expert panel on detection, evaluation, and treatment of high blood cholesterol in adults. NIH Publication 2002; 106:3143-421.

8. Craig WJ. Health-promoting properties of common herbs. Am J Clin Nutr 1999;70:491S-9S.

9. Qin Y, Xia M, Ma J, Hao YT, Liu J, Mou HY, et al. Anthocyanin supplementation improves serum LDL- and HDL-cholesterol concentrations associated with the inhibition of cholesteryl ester transfer protein in dyslipidemic subjects. Am J Clin Nutr 2009;90:485-92.

10. Milind P, Gurditta. Basketful benefits of papaya. International Research Journal of Pharmacy 2011; 2(7): 6-12.

11. Rully M, Probosari E. Pengaruh pemberian buah pepaya (Carica papaya L.) terhadap kadar trigliserida pada tikus Sprague Dawley dengan hiperkolesterolemia. Journal of Nutrition College 2012; 1(1):142-154.

12. Zhao HL, Sim JS, Shim SH, Ha YW, Kang SS, Kim YS. Antiobese and hypolipidemic effects of platycodin saponins in diet-induced obese rats: evidences for lipase inhibition and calorie intake
restriction.International Journal of Obesity (2005) 29, 983-990.

13. Elekofehinti OO, Adanlawo IG, Saliu JA, Sodehinde SA. Saponins from Solanum anguivi fruits exhibit hypolipidemic potential in Rattusnovergicus. Der Pharmacia Lettre, 2012, 4 (3):811-814.

14. Kothari S, Jain AK, Mehta SC, Tonpay SD. Hypolipidemic effect of fresh Triticum aestivum(wheat) grass juice in hypercholesterolemic rats. Acta Poloniae Pharmaceutica and Drug Research, Vol. 68 No. 2 pp. 291ก̃294, 2011.

15. Nuraini M. Pengaruh pemberian jus biji pepaya (Carica papaya Linn) terhadap penurunan kadar low density lipoproteins (LDL) plasma tikus sprague dawly. Yogyakarta: Program Sarjana Kedokteran dan Ilmu Kesehatan, Universitas Muhammadiyah Yogyakarta.

16. Adeneye AA, Olagunju JA. Preliminary hypoglycemic and hypolipidemic activities of the aqueousseed extract of Carica papaya Linn. in wistar rats. Biology and Medicine 2009; 1: 1-10.

17. Supranto J. Teknik Sampling untuk Survey dan Eksperimen. Jakarta : Penerbit PT Rineka Cipta; 2000.

18. Dwiloka B. Efek Kolesterolemik Berbagai Telur.Media Gizi dan Keluarga, Desember 2003, 27 (2): 58-65.

19. United States Department of Agriculture. Nutrient data for 01140, Egg, quail, whole, fresh, raw. National Nutrient Database for Standard Reference 2012 March 30 [cited 2012 July 30]. Available from URL: http://ndb.nal.usda.gov/ndb/foods/show/128

20. Sharp PE, Regina MCL. The Laboratory Rat. USA: CRC Press LLC; 1998.

21. Dahlan MS. Statistik untuk Kedokteran dan Kesehatan. Jakarta: Salemba Medica; 2008.

22. Yuniwati M, Ani P. Optimasi Kondisi Proses Ekstraksi Minyak Biji Pepaya. Jurnal Teknologi Technoscientia 2008;1:78-84.

23. Botham KM, Mayes PA. Pengangkutan dan Penyimpanan Lipid. In: Murray RK, Granner DK, Rodwell VW, editors. Biokimia Harper. 27th ed. Jakarta: Penerbit Buku Kedokteran EGC; 2006. p.225-37.

24. Bender DA, Mayes PA. Tinjauan Umum Metabolisme dan Penyediaan Bahan Bakar Metabolik. In: Murray RK, Granner DK, Rodwell VW, editors. Biokimia Harper. 27th ed. Jakarta: Penerbit Buku Kedokteran EGC; 2006. p.139-50.

25. Gropper SS, Smith JL, Groff JL. Advanced Nutrition and Human Metabolism Fifth Edition. Canada: Wadsworth; 2009. p.131-74.

26. Ibekwe HA, Adinya IB, Onyeama HP, Akpan IA. Diet and alkaloid extract of Garcinia Kola induce reduction in serum levels of selected indices of coronary heart disease and liver functions. African 
Journal of Food Science and Technology (ISSN: 2141-5455) Vol. 4(4) pp. 80-83, April 2013

27. Sari LJ. Gambaran histopatologi hati tikus (Rattus rattus) pada uji toksisitas sub-akut senyawaan asam amino non-protein daun lamtoro merah (Acacia villosa). Undergraduate thesis (2006), Bogor Agricultural University.

28. Begriche K, Massart J, Robin MA, Sanchez AB, Fromenty B. Drug-induced toxicity on mitochondria and lipid metabolism: Mechanistic diversity and deleterious consequences for the liver.Journal of Hepatology 2011 vol. 54 j 773794.

29. Baiduri I, Intan Baiduri (2012) Pengaruh Pemberian Yoghurt Kedelai Hitam (Black Soyghurt) terhadap Kadar Trigliserida Serum pada Tikus Hipertrigliseridemia. Undergraduate thesis, Diponegoro University. 